\title{
PERANCANGAN SISTEM REKOMENDASI INFLUENCER MENGGUNAKAN KNOWLEDGE-BASED FILTERING
}

\author{
Rizki Ridho Novandra ${ }^{1}$ \\ Hery Heryanto ${ }^{2}$ \\ ${ }^{1,2}$ Sekolah Tinggi Manajemen Informatika dan Komputer LIKMI \\ Jl. Ir. H. Juanda no 96 Bandung \\ mail.rizkirn@gmail.com ${ }^{1}$ \\ hery.hrynto@gmail.com ${ }^{2}$
}

\begin{abstract}
ABSTRAK
Media sosial merupakan pangsa pasar yang sangat besar bagi pelaku usaha karena memiliki jumlah pengguna yang tinggi. Hal ini dapat dimanfaatkan oleh pelaku usaha untuk memasarkan produk atau jasa mereka dengan bantuan influencer. Pemilihan influencer yang tepat dapat meningkatkan jumlah transaksi, namun pemilik usaha juga dapat mengalami kerugian apabila bekerja sama dengan influencer bercitra negatif.

Salah satu cara menemukan influencer yang tepat adalah dengan menggunakan sistem rekomendasi berbasis knowledge-based filtering. Sistem ini dapat menerima masukan dari pengguna sesuai kebutuhan usaha masing-masing dan mengeluarkan rekomendasi influencer. Sistem rekomendasi memanfaatkan dua atribut, yaitu engagement rate dan growth rate. Engagement rate digunakan sebagai indikator keaktifan komunikasi antara influencer dengan follower. Growth rate digunakan sebagai indikator popularitas influencer.
\end{abstract}

Kata kunci: sistem rekomendasi, influencer, knowledge-based filtering.

\section{PENDAHULUAN}

Menurut penelitian yang dilakukan oleh Statista pada tahun 2018, terdapat sekitar 4,2 miliar pengguna internet aktif dan 3,4 miliar dari mereka adalah pengguna media sosial. Data tersebut menunjukkan bahwa bisnis apapun yang dijalankan memiliki target pasar yang potensial di media sosial. Hanya saja, data tersebut tidak akan berarti apabila tidak didukung dengan strategi dan rencana pemasaran melalui media sosial yang tepat dan efektif (Diamond, 2019).

Salah satu strategi pemasaran yang dapat dilakukan di media sosial adalah dengan menggunakan influencer marketing. Influencer marketing merupakan sebuah seni dan ilmu untuk berinteraksi dengan seseorang yang memiliki pengaruh di internet supaya mereka mau mempromosikan suatu produk atau jasa tertentu kepada pengikut mereka. Alasan dibalik pemilihan influencer marketing adalah manusia cenderung untuk mengikuti atau mempercayai seseorang yang disukai atau dikagumi. Influencer yang memiliki popularitas dan pengetahuan di bidang tertentu dianggap mampu memengaruhi pengikutnya untuk menggunakan produk atau jasa yang dipromosikan (Diamond, 2019). 
Hanya saja, memilih influencer yang tepat untuk mempromosikan produk atau jasa tidak mudah. Apabila salah memilih influencer, hal ini dapat berpengaruh pada citra bisnis di mata konsumen. Selain itu, hasil yang didapatkan bisa kurang optimal karena kinerja influencer yang kurang maksimal dalam mempromosikan produk atau jasa tersebut (Backaler, 2018). Oleh karena itu, pemilik usaha harus berhati-hati apabila memutuskan menggunakan influencer marketing untuk melakukan promosi.

\section{MASALAH DAN TUJUAN PENELITIAN} berikut :

Penelitian ini akan membahas beberapa rumusan masalah. Di antaranya adalah sebagai

1. Sistem rekomendasi seperti apa yang dapat diterapkan oleh pemilik usaha untuk mencari influencer?

2. Atribut-atribut apa saja yang bisa dijadikan acuan sebagai penentu rekomendasi pada sistem rekomendasi?

Sedangkan tujuan dari penelitian ini adalah sebagai berikut:

1. Menganalisis dan merancang sistem rekomendasi influencer berbasis knowledge-based filtering.

2. Mengidentifikasi dan menghitung bobot atribut-atribut yang dapat dijadikan acuan sebagai penentu rekomendasi

Penelitian ini juga memiliki batasan, yaitu:

1. Fokus hanya pada knowledge-based filtering karena belum ada penelitian terdahulu terkait sistem rekomendasi influencer.

2. Penelitian tidak mempertimbangkan sentimen atau reputasi sosial dari influencer terkait.

3. Sistem tidak mempertimbangkan adanya influencer yang melakukan jual-beli follower, likes, atau komentar

\section{LANDASAN TEORI}

3.1. MEDIA SOSIAL

Media sosial merupakan sebuah perangkat lunak atau aplikasi yang memungkinkan penggunanya untuk saling bertemu, menemukan pengguna dengan ketertarikan yang sama, media untuk berkomunikasi dan berbagi konten, dan membangun komunitas. Media sosial dapat dibagi menjadi 10 kategori, yaitu (Anandhan et al., 2018):

1. Perpustakaan digital: Kumpulan dokumen yang disimpan di internet. Biasa digunakan untuk museum, institusi pendidikan, atau perpustakaan kota.

2. Forum: Media untuk berinteraksi antar sesama pengguna melalui pertanyaan atau opini. Contohnya, Quora, Kaskus, dan Stack Overflow.

3. E-Commerce: Media bagi pengguna, baik pembeli atau penjual, untuk saling berkomunikasi dan berkontribusi dalam melakukan pembelian atau penjualan barang. Contohnya, Amazon, Tokopedia, dan Shopee.

4. Hiburan: Media bagi pengguna untuk berbagi video, musik, atau komunikasi melalui video (streaming). Contohnya, Instagram, YouTube, dan Spotify.

5. Blog atau microblog: Pengguna dapat membagikan konten berupa tulisan yang mengandung gambar atau video kepada pengikut mereka. Contohnya, Wordpress, Twitter, dan Tumblr. 
6. Jaringan sosial: Digunakan untuk membuat koneksi virtual dengan pengguna lain sehingga bisa saling berinteraksi. Contohnya, Facebook dan LinkedIn.

7. Geolocation: Memungkinkan penggunanya untuk membagikan lokasi mereka saat ini kepada pengikut di media sosial. Contohnya, Foursquare.

8. Permainan sosial: Permainan yang dimainkan oleh banyak orang secara virtual melalui jaringan internet. Contohnya, permainan kartu, permainan papan, dan Massively Multiplayer Online Role-Playing Game (MMORPG).

9. Social bookmarking: Digunakan oleh pengguna untuk menyimpan beberapa konten dalam satu tempat. Contohnya, Pinterest, Delicious, dan BibSonomy.

10. Ulasan sosial: Digunakan oleh pengguna untuk membagikan pengalaman mereka setelah berkunjung ke suatu tempat. Contohnya, TripAdvisor.

\subsubsection{PEMASARAN MEDIA SOSIAL}

Banyak pemilik usaha dan perusahaan yang memanfaatkan media sosial untuk melakukan pemasaran usaha. Pemilik usaha memanfaatkan sifat manusia sebagai makhluk sosial yang cenderung dipengaruhi dan dimotivasi oleh satu sama lain untuk melakukan tindakan tertentu. Manusia juga biasanya dipengaruhi oleh lingkungan sosial mereka dalam melakukan pembelian. Dengan memperluas lingkungan sosial tersebut melalui media sosial, pemilik usaha bisa mengubah pengguna menjadi pembeli melalui rekomendasi antar sesama pengguna.

Tidak semua transaksi membutuhkan rekomendasi dari pengguna lain. Transaksi produk dengan risiko yang rendah, seperti pasta gigi, tidak selalu membuat pengguna mempertimbangkan rekomendasi dari pengguna lain. Pengguna baru mulai lebih sering mempertimbangkan rekomendasi orang lain saat akan melakukan transaksi produk dengan risiko yang tinggi, seperti mobil. Rekomendasi orang lain dalam memengaruhi transaksi pembelian lebih besar terjadi pada saat akan membeli mobil dibandingkan dengan pasta gigi (Singh, 2010).

David Roman, Chief Marketing Officer Lenovo, mengatakan bahwa pemasaran yang memanfaatkan strategi mulut ke mulut merupakan strategi yang paling memberikan dampak. Pengguna sudah mulai kurang percaya terhadap iklan yang dipromosikan oleh perusahaan terkait dan lebih percaya perkataan atau rekomendasi dari orang lain dan tokoh penting terkait produk atau jasa yang akan mereka pilih. Pengguna yang bisa memberikan pengaruh kepada orang lain untuk mengambil keputusan inilah yang disebut sebagai influencer (Backaler, 2018).

\subsubsection{PEMASARAN INFLUENCER}

Dengan menggunakan influencer yang tepat, pelaku usaha dapat meningkatkan keuntungan mereka dengan biaya yang lebih rendah dibandingkan dengan strategi pemasaran yang lain. Selain itu, pelaku usaha juga bisa menyesuaikan target pasar yang akan diincar dengan niche yang dimiliki oleh influencer supaya promosi yang dilakukan tepat sasaran (Backaler, 2018). Meski dianggap sebagai salah satu strategi pemasaran yang efektif dan paling memberikan dampak, menemukan influencer yang tepat tidak mudah. Ada risiko yang harus siap dihadapi oleh pelaku usaha apabila menggunakan influencer. Pertama, pemilik usaha harus menganalisis sendiri performa influencer yang diajak bekerja sama. Influencer bisa saja mengirimkan data statistik seperti kunjungan, jumlah klik, atau jumlah tampilan. Namun, pemilik usaha tidak dapat melihat pembeli yang melakukan transaksi didapatkan dari influencer tersebut atau dari jaringan pemasaran yang lain. 
Kedua, apabila pemilik usaha bekerja sama dengan influencer yang salah, maka hasilnya juga tidak akan optimal. Keberadaan jual beli follower membuat jumlah follower di profil influencer tidak dapat dijadikan acuan. Selain itu, sentimen dan tanggapan publik mengenai influencer juga bisa memengaruhi brand dari pemilik usaha secara langsung. Apabila pemilik usaha bekerja sama dengan influencer yang memiliki citra negatif, maka brand dari pemilik usaha juga bisa ikut dianggap negatif (Backaler, 2018). Oleh karena itu, pemilik usaha harus berhati-hati apabila memutuskan menggunakan influencer marketing untuk melakukan promosi.

\subsection{SISTEM REKOMENDASI}

Sistem rekomendasi bertujuan untuk merekomendasikan barang (produk atau layanan) yang paling cocok kepada pengguna tertentu. Biasanya, sistem akan mempertimbangkan ketertarikan pengguna pada suatu barang, informasi yang berkaitan dengan barang tersebut, dan interaksi antar pengguna (Dong et al., 2020). Sistem rekomendasi dapat melakukan penyaringan informasi supaya informasi yang akan diterima oleh pengguna tidak terlalu banyak. Semakin sedikit dan semakin relevan pilihan yang dimiliki oleh pengguna, maka pengguna akan lebih mudah dalam menentukan keputusan. Semakin mudah pembeli menentukan keputusan, maka akan mempercepat proses transaksi dan membuat pendapatan pemilik usaha meningkat (Isinkaye et al., 2015).

Menurut (Aggarwal, 2016), dalam membangun sebuah sistem rekomendasi, ada tiga model yang dapat digunakan, yaitu collaborative filtering, content-based filtering, dan knowledge-based filtering. Penelitian ini menggunakan model knowledge-based filtering, yaitu model yang didasarkan pada kebutuhan, pengetahuan, dan batasan yang ditentukan oleh pengguna.

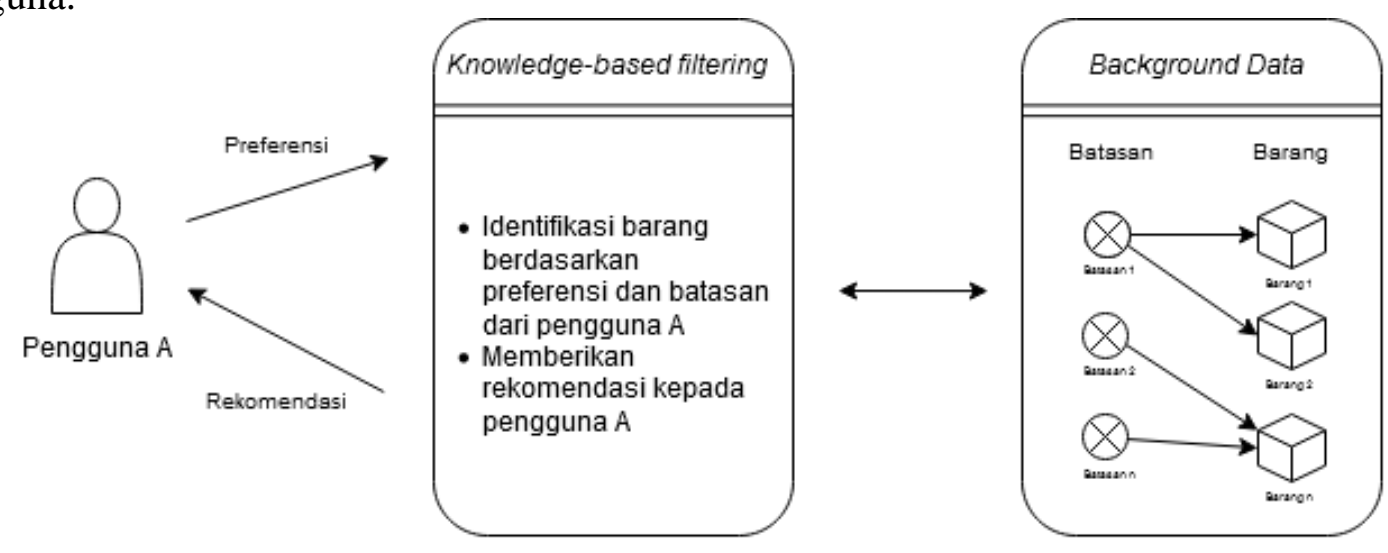

Gambar 1

Alur data knowledge-based filtering

(Walker \& Zimmermann, 2014)

Baik collaborative filtering dan content-based filtering menggunakan data historis mengenai kebiasaan pengguna, penilaian yang pernah dilakukan, atau atribut dan kata kunci yang mirip dengan sebelumnya. Kedua model tersebut rentan terkena permasalahan bernama cold start. Cold start akan terjadi apabila ada pengguna atau barang baru yang tidak memiliki data historis sebelumnya. Tidak adanya data historis membuat pemberian rekomendasi yang menggunakan collaborative filtering dan content-based filtering tidak berjalan dengan optimal (Aggarwal, 2016). 
Permasalahan tersebut dapat diselesaikan dengan knowledge-based filtering, yaitu metode yang menggunakan pengetahuan semantik tentang barang yang akan direkomendasikan. Metode knowledge-based filtering bergantung pada dua jenis data, yaitu data kumpulan aturan (batasan) atau metrik yang sama dan kumpulan barang. Pemberian rekomendasi ini akan didasarkan pada kebutuhan, aturan, atau batasan yang ditentukan oleh pengguna sebelumnya (Walker \& Zimmermann, 2014). Dengan menggunakan knowledge-based filtering, sistem dapat memberikan rekomendasi sesuai keinginan dari pengguna tanpa harus bergantung kepada data historis atau relasi dengan pengguna lain (Aggarwal, 2016).

\subsection{PENELITIAN TERDAHULU}

Pada penelitian terkait sistem rekomendasi, sudah ada beberapa peneliti yang menggunakan knowledge-based filtering pada penelitian mereka, namun belum ada penelitian yang menggunakan topik influencer. Oleh karena itu, penelitian terdahulu yang dipilih merupakan penelitian yang menggunakan knowledge-based filtering, yaitu:

Tabel 1

Penelitian Terdahulu

\begin{tabular}{|l|l|l|l|}
\hline \multicolumn{1}{|c|}{ Penulis } & \multicolumn{1}{|c|}{ Metode } & \multicolumn{1}{c|}{ Topik } & \multicolumn{1}{c|}{ Hasil } \\
\hline $\begin{array}{l}\text { (Carrer-Neto } \\
\text { et al., 2012) }\end{array}$ & $\begin{array}{l}\text { Hybrid } \\
\text { (Collaborative } \\
\text {-filtering dan } \\
\text { knowledge- } \\
\text { based filtering) }\end{array}$ & $\begin{array}{l}\text { Sistem } \\
\text { rekomendasi } \\
\text { film }\end{array}$ & $\begin{array}{l}\text { Sistem memberikan rekomendasi berdasarkan } \\
\text { pada hubungan semantik antara pengguna } \\
\text { dengan konten dan mewarisi rekomendasi dari } \\
\text { media sosial pengguna. Atribut yang dijadikan } \\
\text { sebagai bahan pemberian rekomendasi hanya } \\
\text { terbatas pada satu kategori saja. }\end{array}$ \\
\hline $\begin{array}{l}\text { (Gil et al., } \\
\text { 2019) }\end{array}$ & $\begin{array}{l}\text { Knowledge- } \\
\text { based filtering }\end{array}$ & $\begin{array}{l}\text { Sistem } \\
\text { rekomendasi } \\
\text { informasi } \\
\text { kesehatan dan } \\
\text { medis }\end{array}$ & $\begin{array}{l}\text { Sistem } \\
\text { berdasarkan kondisi kesehatan pasien dan tag } \\
\text { informasi yang sesuai dengan kondisi pasien. } \\
\text { Apabila terdapat tagging yang kurang atau } \\
\text { hilang pada suatu informasi, maka akurasi } \\
\text { rekomendasi juga menurun. }\end{array}$ \\
\hline $\begin{array}{l}\text { (Rosa et al., } \\
\text { 2019) }\end{array}$ & $\begin{array}{l}\text { Knowledge- } \\
\text { based filtering }\end{array}$ & $\begin{array}{l}\text { Sistem } \\
\text { rekomendasi } \\
\text { kesehatan } \\
\text { mental }\end{array}$ & $\begin{array}{l}\text { Sistem mengeluarkan rekomendasi pesan } \\
\text { dengan emosi positif berdasarkan sentimen di } \\
\text { media sosial, profil, lokasi, dan aspek ontologi } \\
\text { pengguna. }\end{array}$ \\
\hline $\begin{array}{l}\text { Lejeda- } \\
\text { 2019) }\end{array}$ & $\begin{array}{l}\text { Knowledge- } \\
\text { based filtering }\end{array}$ & $\begin{array}{l}\text { Sistem } \\
\text { rekomendasi } \\
\text { investasi }\end{array}$ & $\begin{array}{l}\text { Sistem mengeluarkan rekomendasi manajer } \\
\text { investasi berdasarkan profil risiko, preferensi } \\
\text { industri, dan besaran dana yang dimiliki } \\
\text { pengguna. }\end{array}$ \\
\hline $\begin{array}{l}\text { (Dong et al., } \\
\text { 2020) }\end{array}$ & $\begin{array}{l}\text { Knowledge- } \\
\text { based filtering }\end{array}$ & $\begin{array}{l}\text { Sistem } \\
\text { rekomendasi } \\
\text { produk } \\
\text { fashion } \\
\text { kepada pengguna berdasarkan bentuk tubuh, } \\
\text { tema dan gaya fashion, jenis pakaian, jenis } \\
\text { kain, serta warna. Penelitian ini menentukan } \\
\text { rekomendasi berdasarkan hubungan antar } \\
\text { atribut yang ditentukan dengan menggunakan } \\
\text { fuzzy relational model }\end{array}$ \\
\hline
\end{tabular}


Apabila dibandingkan dengan penelitian terdahulu, penelitian ini memiliki beberapa perbedaan sebagai berikut:

1. Topik penelitian ini berupa sistem rekomendasi influencer yang belum pernah diteliti sebelumnya sehingga atribut yang akan ditentukan sebagai penentu rekomendasi belum ada.

2. Penelitian tidak mempertimbangkan analisis sentimen karena minimnya media untuk para pelaku usaha berbagi pendapat mereka mengenai kinerja influencer.

3. Penentuan atribut tidak berdasarkan hubungan antar atribut, melainkan pembobotan masing-masing atribut.

4. Data yang diambil hanya data pelaku usaha, bidang usaha, dan influencer.

5. Pengujian menggunakan metode kualitatif untuk menilai kecocokan influencer yang direkomendasikan dengan bidang usaha dan anggaran.

\section{ANALISIS DAN PERANCANGAN}

Penelitian ini melalui delapan tahapan pada saat pengembangannya, yaitu

1. Pengumpulan Data. Pada tahap ini, peneliti akan mengumpulkan data influencer dari media sosial Instagram. Pengambilan data dilakukan menggunakan Profia, sistem informasi influencer milik PT Hivemind Digital Media. Instagram dipilih karena data-data yang disajikan cukup lengkap, mulai dari jumlah follower, niche, engagement tiap post, sampai insight. Setelah data berhasil dikumpulkan, peneliti akan mencoba memahami atributatribut yang dimiliki oleh influencer sebelum mengkorelasikannya sebagai bahan rekomendasi.

2. Identifikasi atribut. Pada tahap ini dilakukan identifikasi atribut yang dimiliki oleh pemilik bisnis dan influencer. Identifikasi ini bertujuan untuk menggali atribut apa saja yang terlihat, seperti jumlah pengikut atau komentar, dan atribut yang tidak terlihat secara langsung, seperti average view, komentar, atau like.

3. Filtering atribut. Pada tahap ini, atribut yang berhasil diidentifikasi akan ditentukan mana yang bisa dijadikan sebagai constraint bagi pemilik usaha. Tidak semua atribut akan digunakan sehingga pada tahap ini akan dilakukan filtering.

4. Pengkategorian data. Data atribut yang sudah disaring akan dikategorikan berdasarkan karakteristik masing-masing atribut. Contohnya, atribut jumlah follower akan dikelompokkan menjadi nano, mikro, sampai makro.

5. Pembobotan. Setelah berhasil menentukan atribut yang akan dijadikan sebagai dasar rekomendasi, langkah selanjutnya adalah menentukan bobot dari masing-masing atribut untuk memudahkan dalam pemberian peringkat rekomendasi. Penentuan bobot juga akan didasarkan dari literatur terkait. Alasan pemilihan literatur dikarenakan belum adanya sistem ulasan dari para pelaku online terkait kinerja dari influencer. Ulasan yang saat ini ada hanya berupa spreadsheet yang berisi daftar blacklist influencer saja.

6. Perancangan. Pada tahap ini, peneliti akan merancang flowchart, basis data, dan antar muka dari sistem rekomendasi. Rancangan yang dihasilkan akan dijadikan sebagai dasar implementasi.

7. Implementasi. Berdasarkan hasil perancangan akan dilakukan implementasi menggunakan bahasa pemrograman Phyton. Proses yang akan dirancang mulai dari pemilik usaha masuk ke dalam sistem sampai mendapatkan keluaran berupa influencer yang direkomendasikan 
8. Evaluasi. Tahap evaluasi ini merupakan tahap akhir dari penelitian yang dilakukan. Aktivitas yang dilakukan pada tahap ini adalah melakukan evaluasi hasil rekomendasi dengan menilai kesesuaian antara hasil dan penjelasan dari rekomendasi.

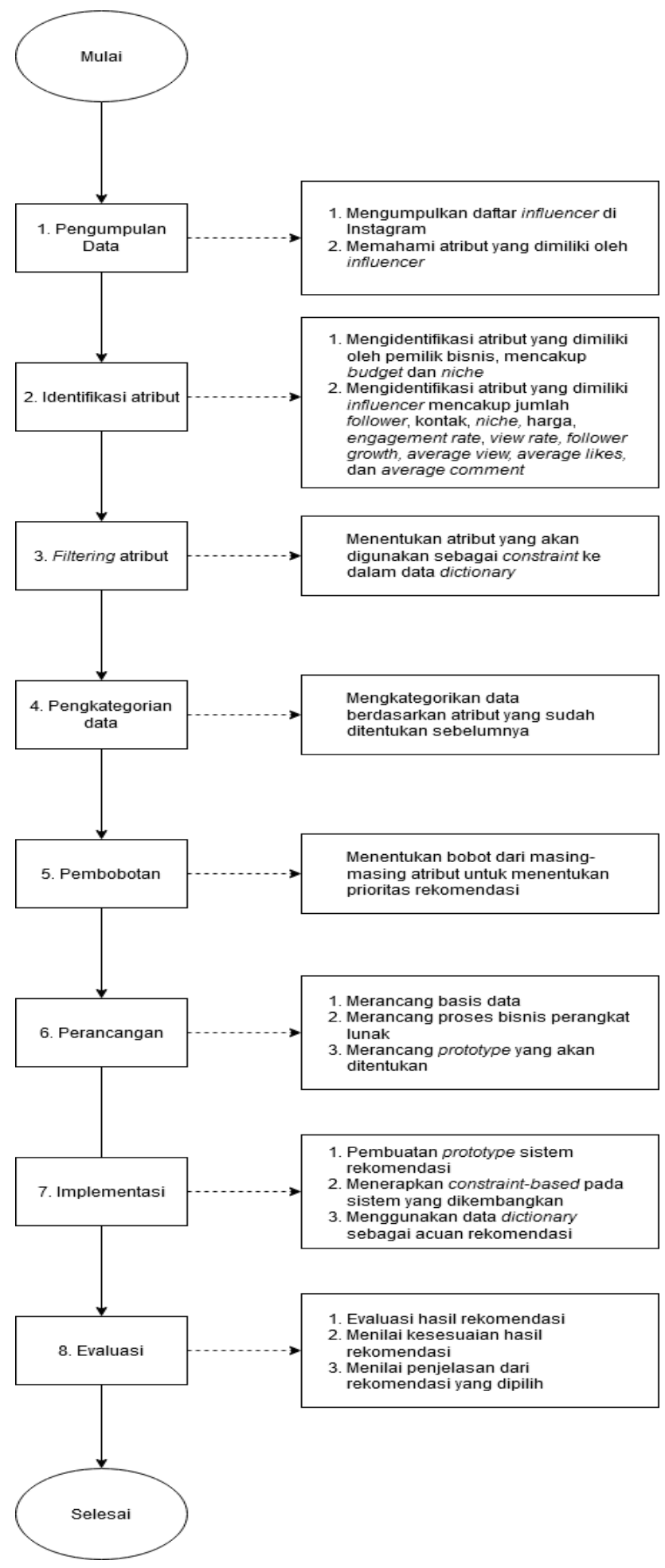

Gambar 2

Tahapan Penelitian 


\section{HASIL DAN PEMBAHASAN}

\subsection{PENGUMPULAN DATA}

Data influencer didapatkan dari Profia, sistem informasi influencer milik PT Hivemind Digital Media. Data yang diambil untuk penelitian ini mencakup 100 influencer dari berbagai kategori, mulai dari fashion, makanan, games, kecantikan, dan travel.

\subsection{IDENTIFIKASI ATRIBUT}

Tabel 2 menunjukkan 25 atribut yang dimiliki influencer, yaitu:

Tabel 2

Penjelasan masing-masing atribut

\begin{tabular}{|l|l|}
\hline \multicolumn{1}{|c|}{ Atribut } & \multicolumn{1}{c|}{ Penjelasan } \\
\hline Nama & Nama influencer \\
\hline Username & Username Instagram influencer \\
\hline Followers & Jumlah total followers yang dimiliki oleh influencer \\
\hline Engagement rate & Tingkat keterlibatan follower pada konten \\
\hline Growth rate & Tingkat pertumbuhan follower dalam 30 hari terakhir \\
\hline Average likes & Rata-rata likes yang dimiliki oleh influencer \\
\hline Average comments & Rata-rata komentar yang dimiliki oleh influencer \\
\hline Engagements & Reaksi pengguna pada konten \\
\hline Ratio & Rasio antara jumlah komentar dan likes yang dimiliki \\
\hline Growth & Pertumbuhan follower dalam periode tertentu \\
\hline Est. Reach & Perkiraan jangkauan dari konten yang diiklankan \\
\hline Posts & Jumlah total postingan \\
\hline Latest Post at & Waktu terakhir kali mengunggah postingan \\
\hline Lokasi & Tempat domisili influencer \\
\hline Kategori & Kategori atau niche yang dimiliki influencer \\
\hline Latest Posts & Postingan terbaru yang diunggah \\
\hline Latest Mentions & Mention terbaru yang dilakukan \\
\hline Latest Hashtags & Hashtag terakhir yang dicantumkan dalam postingan \\
\hline Harga Foto & Tarif iklan berupa foto di feed \\
\hline Harga Stories & Tarif iklan berupa foto atau video di Stories \\
\hline Harga Video & Tarif iklan berupa video di feed \\
\hline Jumlah Foto & Jumlah foto yang diiklankan \\
\hline Jumlah Stories & Jumlah Stories yang diunggah \\
\hline Jumlah Video & Jumlah video yang diiklankan \\
\hline Total & Total harga dengan jumlah \\
\hline
\end{tabular}

\subsection{FILTERING ATRIBUT}

Pada tahap ini, 25 atribut pada data influencer yang sudah dikumpulkan sebelumnya tidak akan ditampilkan semua kepada pengguna. Atribut-atribut tersebut akan dipilah sebelum dikelompokkan sesuai dengan kategorinya masing-masing. Proses filtering atribut didasarkan pada masukan ahli. Ahli yang penulis pilih merupakan CEO, pendiri PT Hivemind Digital Media, dan praktisi digital marketing yang telah mengerjakan proyek pemasaran melalui media 
digital untuk beberapa industri dan usaha. Daftar atribut yang akan ditampilkan dapat dilihat pada Tabel 3.

Tabel 3

Daftar Atribut yang Ditampilkan

\begin{tabular}{|c|c|}
\hline $\begin{array}{l}\text { Atribut yang } \\
\text { Ditampilkan }\end{array}$ & Penjelasan \\
\hline Nama & Nama digunakan untuk mengidentifikasi influencer. \\
\hline Username & $\begin{array}{l}\text { Sama seperti nama, digunakan untuk identifikasi dan pembeda } \\
\text { antara influencer dengan yang lain. }\end{array}$ \\
\hline Followers & $\begin{array}{l}\text { Jumlah follower digunakan sebagai screening awal pemilik } \\
\text { usaha dalam memilih influencer yang sesuai dengan biaya yang } \\
\text { dimiliki. Semakin besar follower, kemungkinan biaya } \\
\text { pemasaran yang dikeluarkan juga akan semakin tinggi. }\end{array}$ \\
\hline Kategori & $\begin{array}{l}\text { Kategori digunakan untuk memudahkan pemilik usaha dalam } \\
\text { memilih influencer yang sesuai dengan niche bisnis mereka. }\end{array}$ \\
\hline Lokasi & $\begin{array}{l}\text { Lokasi digunakan untuk memudahkan pemilik usaha dalam } \\
\text { bertemu dengan influencer secara langsung. Lokasi juga bisa } \\
\text { digunakan untuk memetakan demografi follower dari } \\
\text { influencer, sehingga pemilik usaha bisa mencocokkannya } \\
\text { dengan demografi target pasar. }\end{array}$ \\
\hline Harga Foto & $\begin{array}{l}\text { Harga foto digunakan untuk melihat harga yang ditawarkan } \\
\text { oleh influencer untuk konten foto yang akan dipromosikan. } \\
\text { Harga tidak dapat dijadikan patokan utama karena sifatnya } \\
\text { fluktuatif dan dinamis bergantung dari influencer. }\end{array}$ \\
\hline Harga Stories & $\begin{array}{l}\text { Harga stories digunakan untuk melihat harga yang ditawarkan } \\
\text { oleh influencer untuk konten stories yang akan dipromosikan. } \\
\text { Harga tidak dapat dijadikan patokan utama karena sifatnya } \\
\text { fluktuatif dan dinamis bergantung dari influencer. }\end{array}$ \\
\hline Harga Video & $\begin{array}{l}\text { Harga video digunakan untuk melihat harga yang ditawarkan } \\
\text { oleh influencer untuk konten video yang akan dipromosikan. } \\
\text { Harga tidak dapat dijadikan patokan utama karena sifatnya } \\
\text { fluktuatif dan dinamis bergantung dari influencer. }\end{array}$ \\
\hline Jumlah Foto & $\begin{array}{l}\text { Jumlah foto mencakup total konten foto yang akan } \\
\text { dipromosikan sesuai dengan harga foto. }\end{array}$ \\
\hline Jumlah Stories & $\begin{array}{l}\text { Jumlah foto mencakup total konten stories yang akan } \\
\text { dipromosikan sesuai dengan harga stories. }\end{array}$ \\
\hline Jumlah Video & $\begin{array}{l}\text { Jumlah foto mencakup total konten video yang akan } \\
\text { dipromosikan sesuai dengan harga video. }\end{array}$ \\
\hline Total Harga & $\begin{array}{l}\text { Total harga merupakan perhitungan total antara harga dengan } \\
\text { jumlah. }\end{array}$ \\
\hline
\end{tabular}

Atribut-atribut yang dipilih pada Tabel 3 merupakan atribut yang akan dipertimbangkan sebagai indikator pemilihan influencer. Atribut lain seperti growth rate dan engagement rate akan dipertimbangkan sebagai acuan dalam menentukan rekomendasi. Atribut growth rate 
dipilih sebagai salah satu indikator penentuan rekomendasi untuk melihat pertumbuhan follower yang dimiliki oleh influencer. Influecer yang aktif di media sosial atau memiliki konten yang viral cenderung mengalami peningkatan follower. Influencer yang kurang aktif cenderung memiliki nilai growth rate yang tidak cukup tinggi. Atribut growth rate memang bisa melihat pertumbuhan follower, namun atribut ini belum tentu bagus karena influencer yang sedang terkena skandal atau memiliki konten negatif terkadang juga mengalami pertumbuhan atau penurunan jumlah follower. Atribut engagement rate juga bisa dijadikan salah satu indikator penentuan rekomendasi untuk melihat tingkat interaksi antara influencer dan follower. Influencer yang memiliki engagement rate cukup tinggi berarti menjalin komunikasi dua arah yang cukup baik dengan follower. Hal ini dapat dijadikan acuan oleh pemilik usaha untuk memastikan konten yang dipromosikan mendapat umpan balik dari follower.

\subsection{PEMBOBOTAN ATRIBUT}

Atribut yang akan dijadikan sebagai indikator penentuan rekomendasi akan ditentukan bobot atau prioritasnya berdasarkan masukan ahli. Ahli menentukan prioritas atribut berdasarkan pengalaman dan riset dalam menangani klien. Pemetaan atribut-atribut ini dapat dilihat pada Gambar 3.

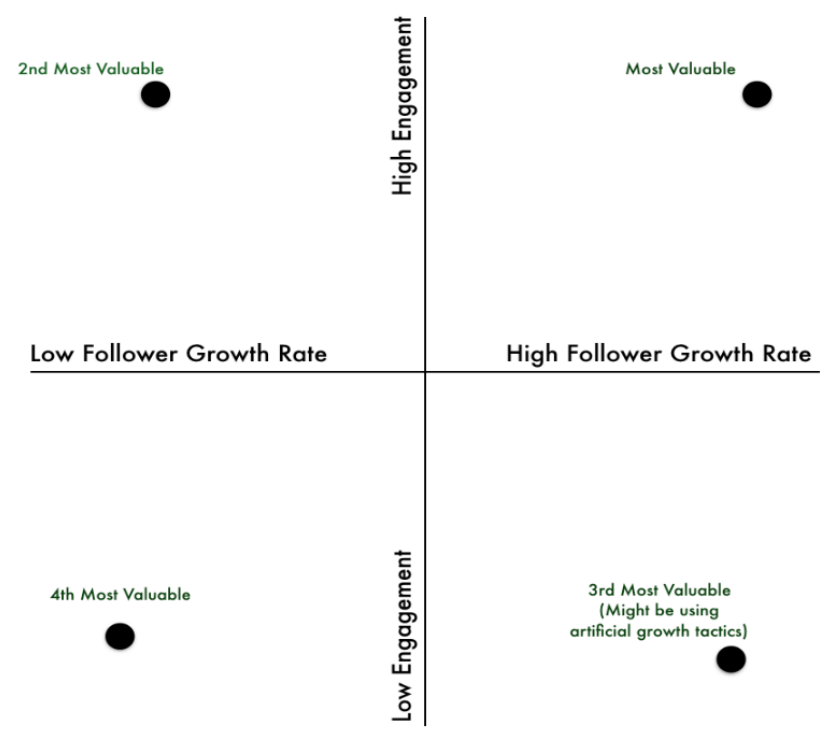

Gambar 3

Pemetaan atribut penentu rekomendasi

Pada Gambar 3, atribut engagement dan growth rate influencer dijadikan sebagai acuan dalam penentu rekomendasi. Influencer dengan engagement dan growth rate yang tinggi akan diprioritaskan sebagai rekomendasi. Influencer dengan engagement yang tinggi namun growth rate yang rendah menempati prioritas yang kedua.

\subsection{PERANCANGAN SISTEM}

Sebelum membangun sistem rekomendasi yang diinginkan, diperlukan rancangan supaya sistem yang diinginkan dapat berjalan sesuai dengan yang diinginkan. Perancangan ini meliputi flowchart, basis data, dan tampilan 


\subsubsection{FLOWCHART}

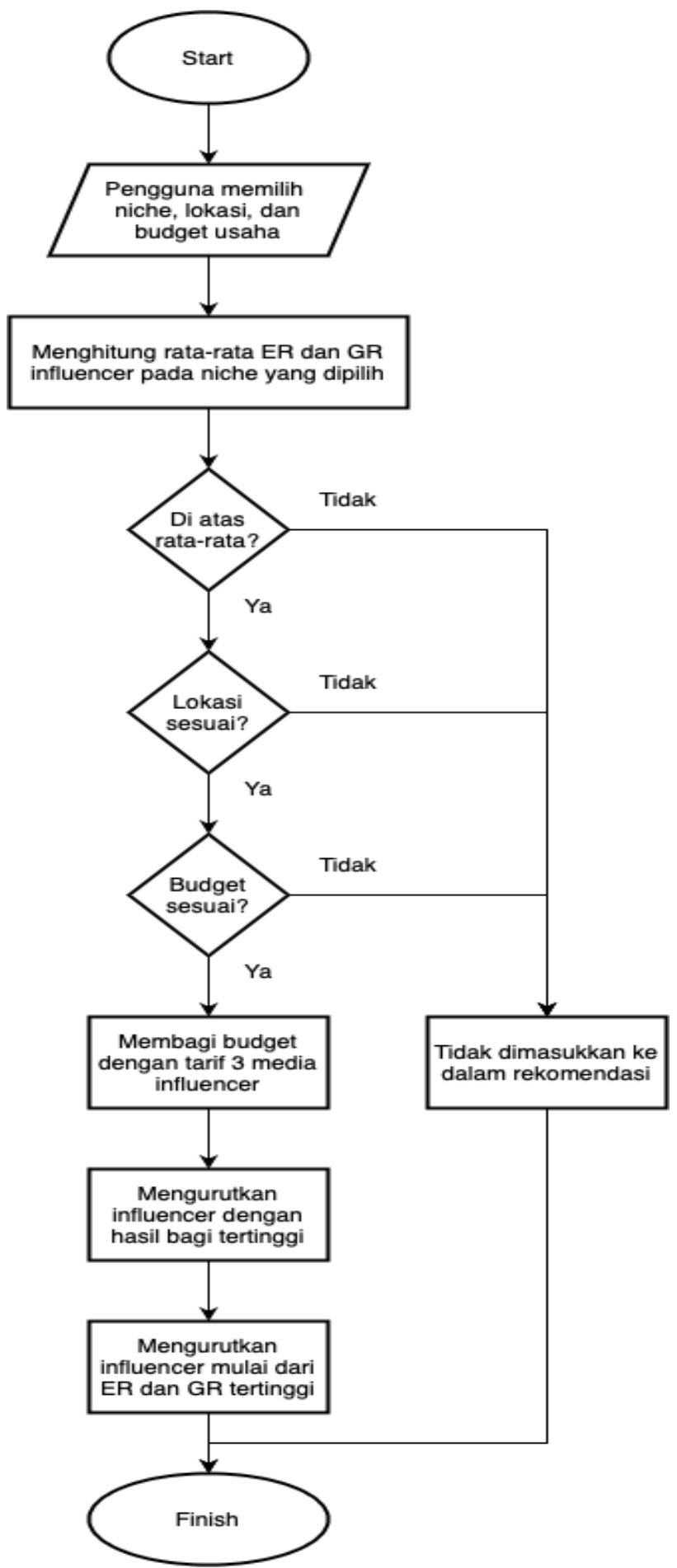

Gambar 4

Flowchart Alur Sistem

Pada Gambar 4, dapat dilihat bahwa sistem akan menerima masukan dari pengguna dan melakukan penyaringan data berdasarkan masukan tersebut. Data influencer yang sudah didapatkan akan dihitung rata-rata engagement rate dan growth rate. Influencer yang memiliki 
nilai di atas rata-rata akan diprioritaskan. Nilai atribut tersebut akan dihitung sesuai bobot dan influencer yang memiliki total nilai tertinggi akan diprioritaskan kepada pengguna.

\subsubsection{BASIS DATA}

Rancangan basis data influencer pada penelitian ini dapat dilihat pada Gambar 5. Atribut yang dimasukkan merupakan atribut yang sudah dipilih pada saat filtering atribut. Atributatribut ini merupakan atribut yang akan dipilih oleh pengguna dan dijadikan sebagai indikator penentu rekomendasi.

\begin{tabular}{|c|c|c|c|c|}
\hline \multirow[t]{3}{*}{ PK } & id_influencer & & & \\
\hline & nama & & & \\
\hline & username & & PK & id_follower \\
\hline \multirow[t]{11}{*}{ FK } & id_follower & 4 & & kategori_follower \\
\hline & engagement_rate & & & min_value \\
\hline & growth_like & & & max_value \\
\hline & avg_likes & & & \\
\hline & avg_comment & & & \\
\hline & engagement & & & \\
\hline & ratio & & & \\
\hline & growth & & & \\
\hline & est_reach & & & \\
\hline & posts & & PK & id_location \\
\hline & latest_post & & & location \\
\hline FK & id_location & 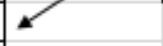 & & \\
\hline \multirow[t]{4}{*}{ FK } & id_niche & & & \\
\hline & rate_photo & -1 & \begin{tabular}{|l|} 
PK \\
\end{tabular} & id_niche \\
\hline & rate_video & & & name_niche \\
\hline & rate_stories & & & \\
\hline
\end{tabular}

\section{Gambar 5}

Rancangan Basis Data

\subsubsection{ANTARMUKA}

Rancangan antar muka sistem dapat dilihat pada Gambar 6. Pengguna dapat memasukkan batasan-batasan yang diinginkan mulai dari jenis usaha, lokasi usaha, dan biaya yang dimiliki oleh pelaku usaha untuk mempromosikan produk atau jasa mereka. Setelah pengguna menentukan batasan tersebut, pengguna dapat menekan tombol Submit untuk mengetahui influencer yang direkomendasikan. Hasil yang ditampilkan kepada pelaku usaha berupa data tabel yang berisi daftar influencer yang sesuai dengan kriteria yang mereka tentukan sebelumnya. Hasil tersebut akan ditambahkan penjelasan mengenai alasan pemilihan infuencer yang masuk ke dalam daftar untuk memudahkan pelaku usaha untuk memilih influencer. Sistem rekomendasi ini akan mengeluarkan beberapa rekomendasi influencer, namun keputusan akhir tetap berada di pelaku usaha. Pelaku usaha dapat memilih influencer yang diiinginkan dari daftar rekomendasi tersebut. 

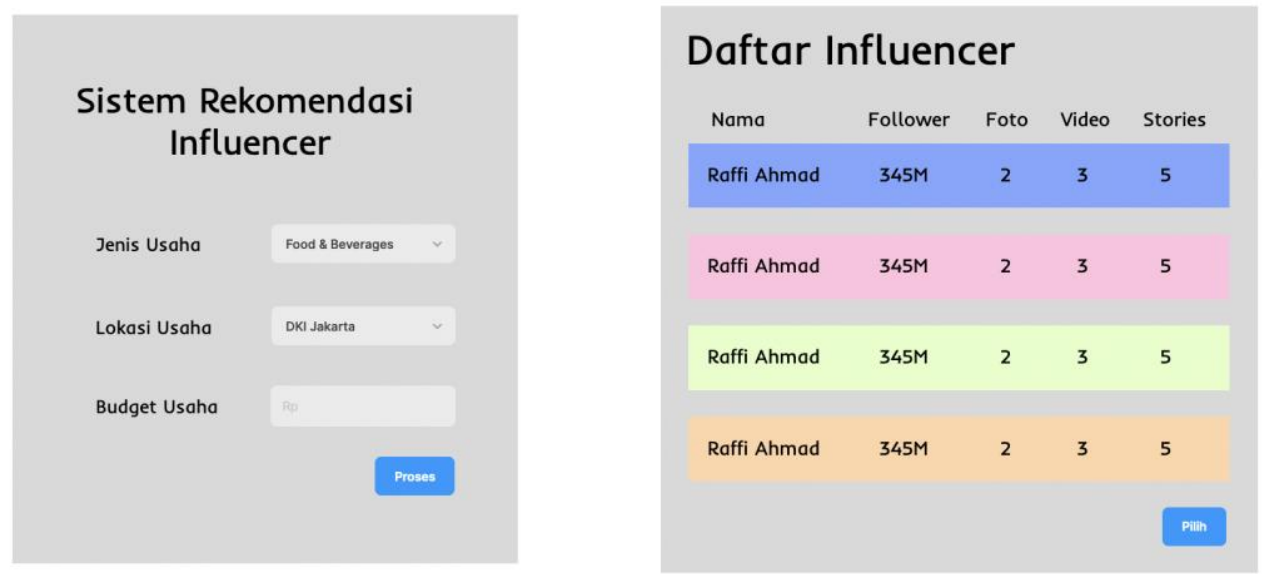

Gambar 6

Rancangan Antarmuka Sistem Rekomendasi

\subsection{HASIL IMPLEMENTASI SISTEM}

Sistem rekomendasi influencer dibangun menggunakan bahasa pemrograman PHP dan basis data MySQL. Pengembangan sistem tidak sepenuhnya mengikuti rancangan sistem yang sudah dijelaskan sebelumnya karena ada pertimbangan-pertimbangan tertentu yang mengharuskan perubahan pada saat tahap implementasi sistem. Perubahan terjadi pada saat implementasi antar muka sistem. Antar muka sistem pada tahap perancangan memungkinkan pelaku usaha memilih influencer berdasarkan kategori atau niche, lokasi usaha, dan biaya promosi yang dimiliki oleh usaha. Pada Gambar 7, biaya promosi diganti oleh kategori follower dari influencer karena data harga foto, video, dan stories dari beberapa influencer berisi 0 atau belum diisi.

\begin{tabular}{l} 
Influencer Recommendation System \\
Kategori: \\
Food \\
Lokasi: \\
Jakarta \\
Follower: \\
Mid-tier \\
\hline Pilih
\end{tabular}

\section{Gambar 7 \\ Tampilan Antarmuka Sistem}

Data harga yang diambil dari Profia belum semua diisi karena harga yang ditawarkan oleh influencer tidak memiliki standar. Influencer bisa menentukan harga sesuai keinginan mereka atau manajer sehingga harga per foto, video, atau stories cukup fluktuatif. Alasan kedua mengapa ada beberapa follower yang belum memiliki data harga karena dari Profia memang belum bisa mendapatkan harga dari influencer tersebut. Tidak semua influencer atau manajer mau langsung menyebutkan angka karena besaran nilai promosi bergantung pada banyak aspek, 
seperti produk yang dipasarkan, kualitas barang, pemilik usaha, brief yang diminta, sampai durasi penayangan. Beberapa influencer tidak memiliki harga yang tetap dan bergantung pada negosiasi.

Pemilihan kategori follower sebagai pengganti biaya promosi didasarkan pada diskusi peneliti dengan ahli. Kategori follower lebih dipilih dibandingkan menampilkan jumlah follower supaya tidak memunculkan bias pada pelaku usaha saat menentukan influencer yang diinginkan. Berdasarkan pengalaman ahli, masih banyak pelaku usaha yang terjebak dengan metrik follower dalam menentukan influencer untuk promosi produk atau jasa. Jumlah follower tidak menjamin promosi yang dilakukan oleh influencer tersebut sukses karena ada faktor yang lebih penting, yaitu engagement rate. Oleh karena itu, sistem rekomendasi ini menggunakan kategori follower. Kategori follower digunakan sebagai acuan pelaku usaha dalam mengeluarkan biaya pemasaran. Pelaku usaha dapat memperkirakan besaran biaya berdasarkan kategori follower dari influencer. Semakin tinggi tingkatan kategori follower seorang influencer, maka harganya juga akan semakin mahal.

1. Penyaringan Berdasarkan Engagement Rate

Setelah pelaku usaha memilih parameter yang diinginkan, sistem akan menghitung ratarata engagement rate dari kategori yang dipilih. Perhitungan ini bertujuan untuk menyaring influencer pada kategori yang ditentukan. Hasil penyaringan ini akan menghasilkan daftar influencer dengan engagement rate yang tinggi atau di atas rata-rata. Masing-masing kategori memiliki standar engagement rate sendiri. Menurut ahli, pada kategori tertentu bisa dengan mudah mendapatkan engagement rate $20 \%$, namun di kategori lain engagement rate sebesar $2 \%$ sudah dianggap sangat baik. Salah satu hal yang mendasari adalah tingkat persaingan dan keaktifan pengguna pada kategori tertentu. Semakin aktif pengguna di suatu kategori, engagement rate pada kategori tersebut juga lebih tinggi. Oleh karena itu, perlu ditentukan standar berupa rata-rata engagement rate pada masing-masing kategori. Penyaringan influencer menggunakan query SQL seperti pada Gambar 4.7.

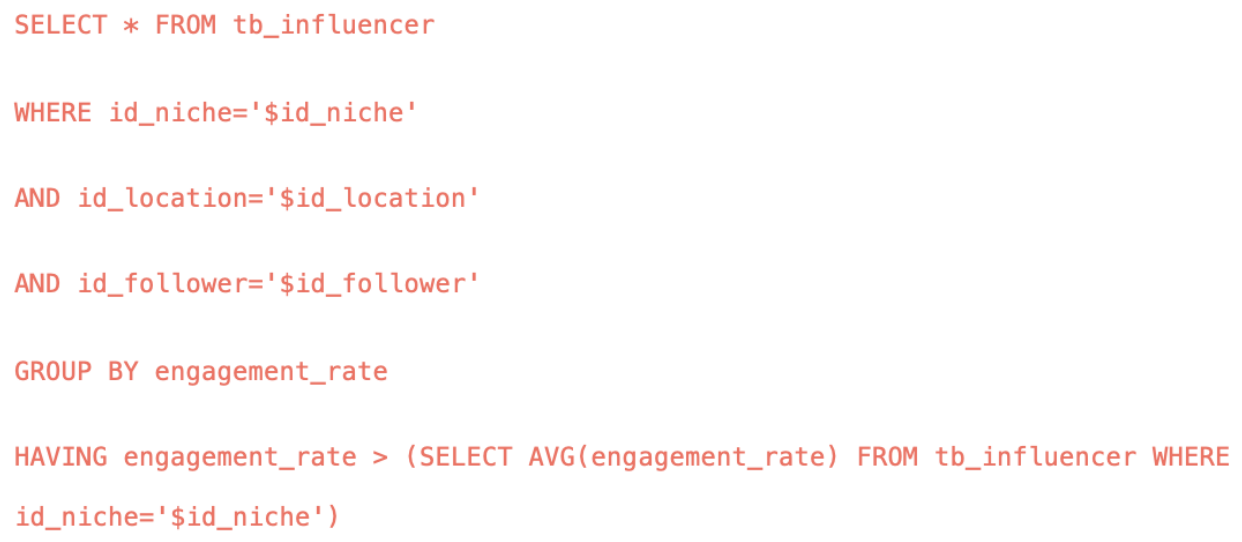

Gambar 8

Query SQL Penyaringan Berdasarkan Engagement Rate 


\section{Pengurutan Growth Rate}

Sistem telah menemukan influencer yang paling aktif atau memiliki interaksi yang intens dengan follower mereka setelah melalui tahap penyaringan. Langkah selanjutnya adalah mengurutkan growth rate influencer dari yang paling tinggi ke yang paling rendah. Pengurutan ini bertujuan untuk memudahkan pelaku usaha dalam memilih influencer yang sedang naik daun. Semakin tinggi nilai growth rate, pertumbuhan follower influencer tersebut juga semakin besar. Apabila growth rate bernilai negatif, maka influencer tersebut sedang mengalami penurunan follower. Sistem tidak melakukan penyaringan growth rate karena naik turunnya follower fluktuatif. Influencer yang memiliki growth rate tinggi dan positif tidak sepenuhnya menguntungkan karena bisa saja pertumbuhan tersebut disebabkan oleh sentimen negatif. Sistem rekomendasi ini masih belum bisa menentukan pertumbuhan growth rate berdasarkan sentimen, sehingga growth rate tidak perlu disaring dan dapat dijadikan sebagai bahan pertimbangan oleh pemilik usaha. Pemilik usaha dapat mencari tahu pertumbuhan growth rate tersebut didasarkan pada sentimen positif atau negatif. Pengurutan growth rate menggunakan query ORDER BY seperti pada Gambar 9.

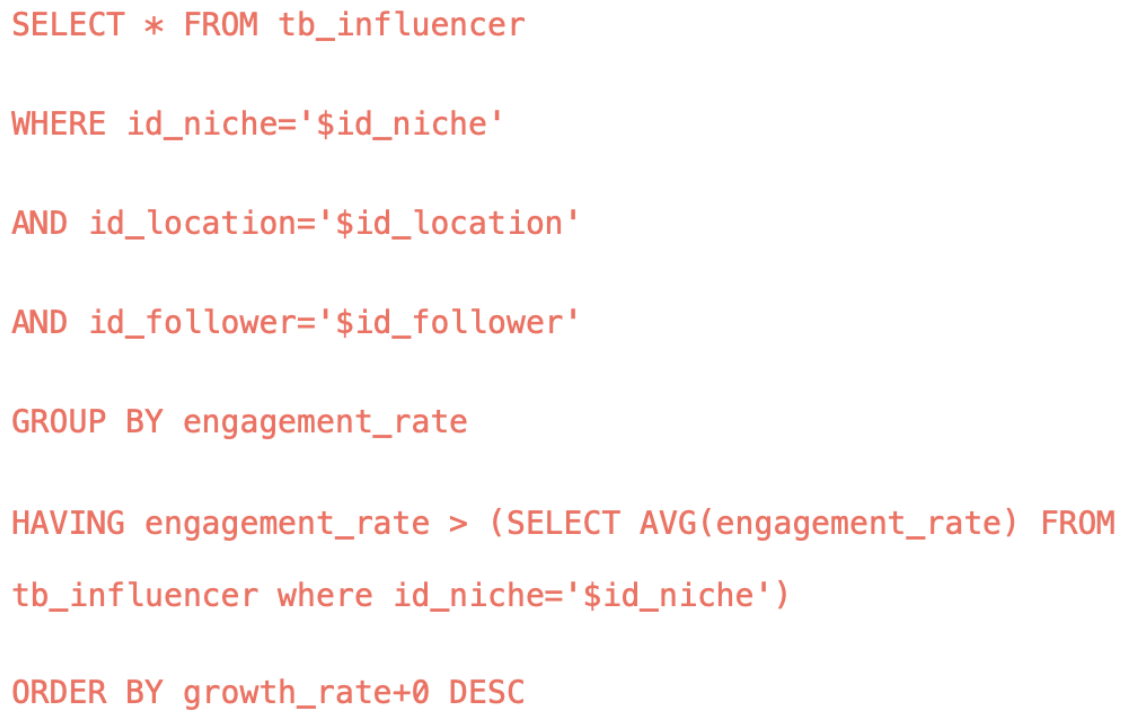

Gambar 9

Query SQL Pengurutan Growth Rate

\section{Pengujian Dan Tampilan Rekomendasi}

Sistem rekomendasi akan menampilkan enam atribut pada hasil rekomendasi dalam bentuk tabel sebagai bahan pertimbangan bagi pemilik usaha. Atribut tersebut antara lain nama, username, follower, kategori atau niche, lokasi, growth rate. Atribut engagement rate tidak ditampilkan karena sistem sudah menampilkan influencer dengan nilai atribut engagement rate yang tinggi. Tampilan rekomendasi dapat dilihat pada Gambar 10, detail influencer yang dipilih dapat dilihat pada Gambar 11, Gambar 12, dan Gambar 13. Query SQL yang digunakan untuk menampilkan rekomendasi influencer dapat dilihat pada Gambar 14. Tampilan hasil rekomendasi menggunakan INNER JOIN tabel influencer, follower, kategori, dan lokasi yang dimasukkan ke dalam sebuah VIEW. 
Influencer Recommendation System

Kategori:

Food

Lokasi:

Jakarta

Follower:

Mid-tier (50.000 - 500.000)

\begin{tabular}{|c|c|c|c|c|c|c|}
\hline No & Username & Nama & Follower & Kategori & Lokasi & Growth Rate \\
\hline 1 & jajanbeken & Bona Food Blogger & Mid-tier $(50.000-500.000)$ & Food & Jakarta & 12,67 \\
\hline 2 & adityaharivonda & Adityaharivonda & Mid-tier $(50.000-500.000)$ & Food & Jakarta & 2,98 \\
\hline 3 & syosuaronald & Yosua Ronald & Mid-tier (50.000 - 500.000) & Food & Jakarta & $-866,00$ \\
\hline
\end{tabular}

Influencer yang direkomendasikan oleh sistem memiliki tingkat interaksi yang TINGGI dengan follower sehingga produk yang dipromosikan berpeluang mendapatkan feedback langsung dari follower influencer yang bersangkutan.

Atribut Growth Rate menunjukkan perkembangan follower dari influencer yang bersangkutan. Semakin TINGGI nilainya, maka semakin BANYAK follower baru yang mengikuti influencer tersebut.

Growth Rate NEGATIF belum tentu buruk karena naik turunnya follower adalah hal yang biasa. Anda harus memastikan bahwa pertumbuhan atau penurunan follower tersebut berasal dari hal yang positif, bukan dari sensasi, skandal, atau hal yang negatif.

Gambar 10

Tampilan Rekomendasi Influencer

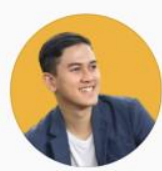

jajanbeken Follow...

3,638 posts $151 \mathrm{k}$ followers $\quad 883$ following

Bona -Food-Blogger

Blogger

- @adieguno

Business Inquiry

WA 087870268009 (Text only)

WWW.JAJANBEKEN.COM

i Jakarta

\#JajanBeken

AAAHOT NOWAAA

www.youtube.com/jajanbeken

followed by cariinfobdg

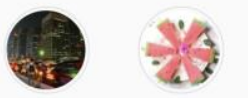

NEW YOU...

BANDUNG
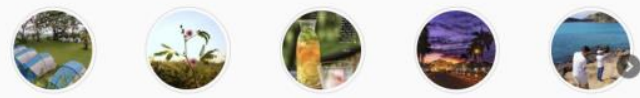

SUKABUMI

BOGOR

SENTUL

JOGJA

เомвок

田 POSTS

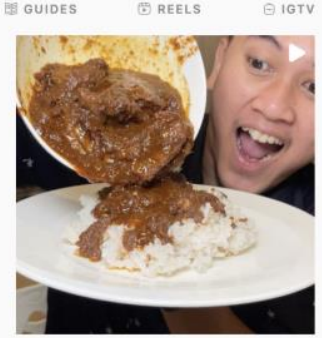

(i) TAGGED
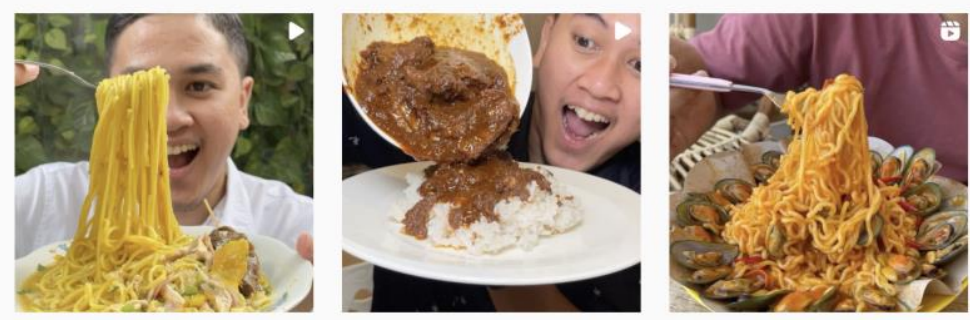

Gambar 11

Influencer pertama hasil rekomendasi sistem 


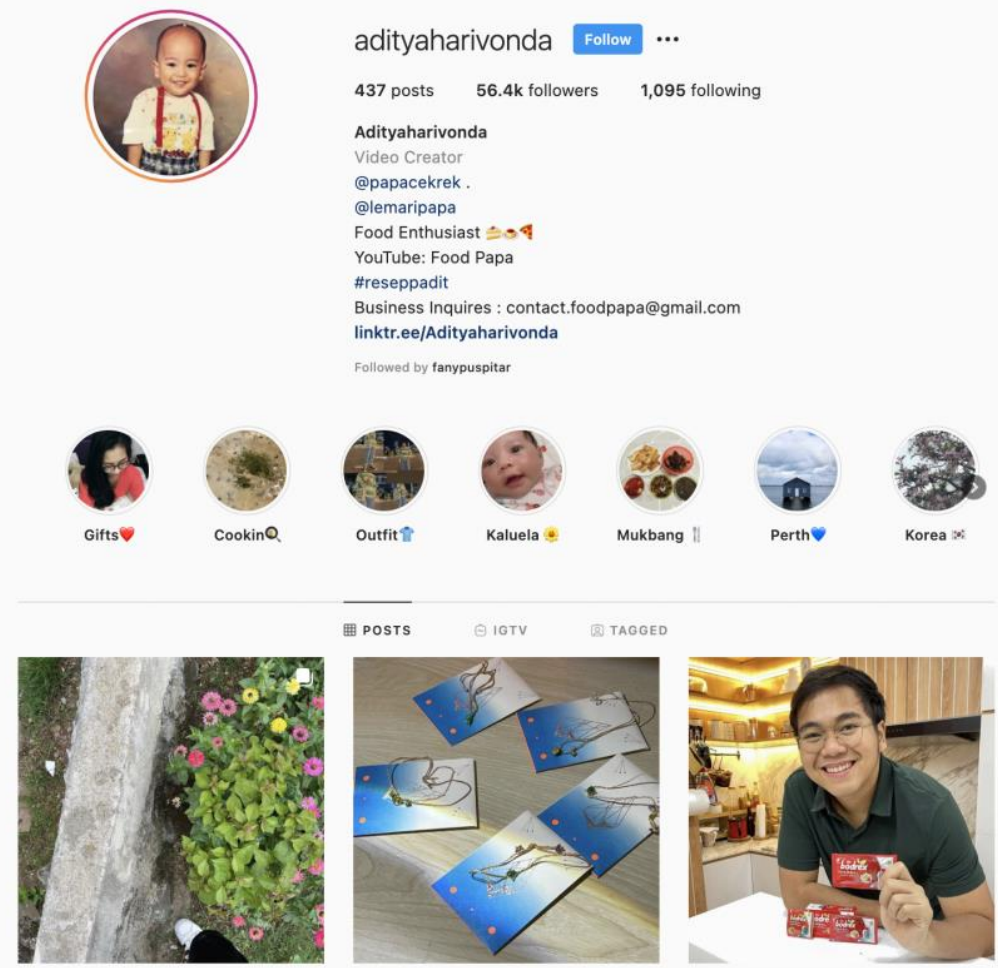

Gambar 12

Influencer kedua hasil rekomendasi sistem

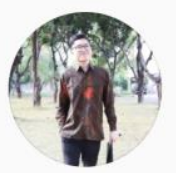

syosuaronald Follow ...

234 posts $\quad 64.1 \mathrm{k}$ followers $\quad 1,303$ following

Yosua Ronald

Social Media Agency

- Social Media Management

- Digital Marketing

Freelance CC (PT Indofood, Thirsty Owl, \& Pappa Jack)

- "Good Design = Good Business"

roomme.id
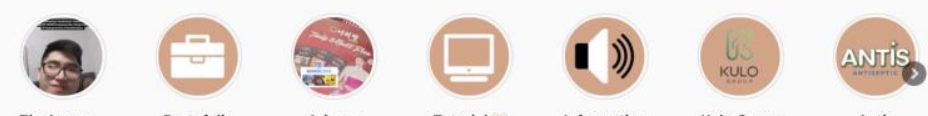

TheAppre.

Portofolio

Arirang

Tutorial $\cdot \cdot$

Information

Kulo Group

Antis

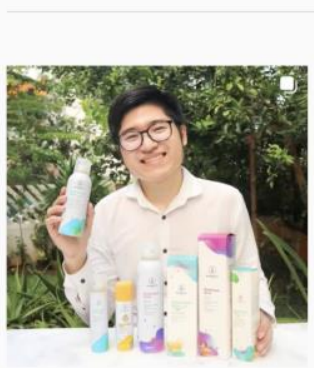

囲 POSTS
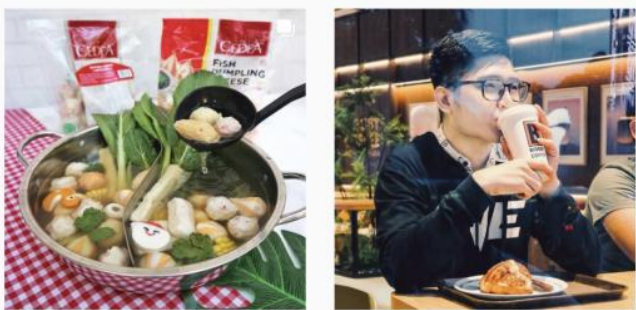

Gambar 13

Influencer ketiga hasil rekomendasi sistem 


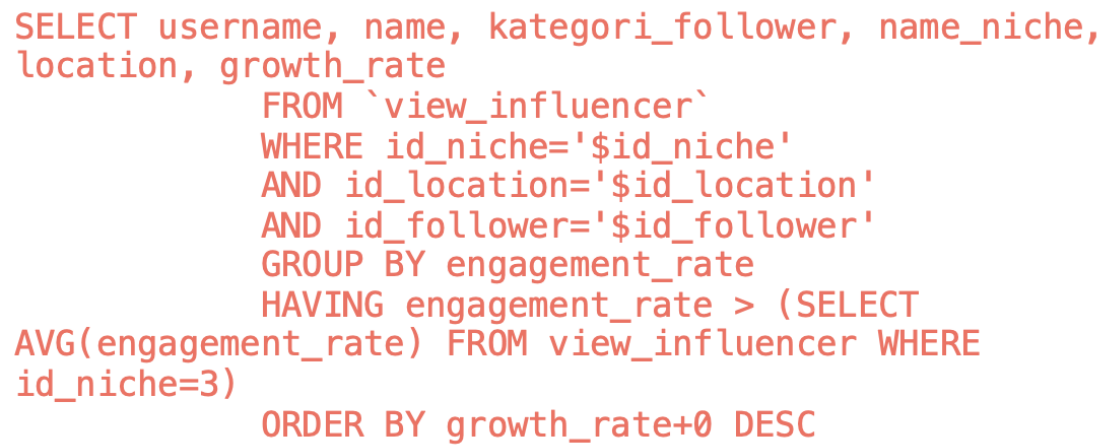

Gambar 14

Query SQL Tampilan Hasil Rekomendasi

\section{KESIMPULAN}

Berdasarkan hasil analisis, perancangan, dan pengujian terhadap sistem rekomendasi influencer, maka dapat ditarik kesimpulan berikut:

1. Sistem rekomendasi yang dapat digunakan oleh pelaku usaha dalam menentukan influencer menggunakan metode knowledge-based filtering. Metode ini memanfaatkan masukan dari pelaku usaha supaya mereka dapat menyesuaikan kebutuhan usaha masing-masing untuk mendapatkan hasil yang diinginkan. Sistem rekomendasi akan memberikan beberapa influencer yang dapat dipilih oleh pelaku usaha dan selanjutnya mereka dapat menentukan sendiri influencer yang diinginkan.

2. Atribut yang bisa dijadikan acuan sebagai penentu rekomendasi pada sistem rekomendasi adalah keaktifan influencer dalam berinteraksi dengan follower. Pelaku usaha juga dapat mencari influencer yang sesuai dengan jenis usaha dan lokasi influencer tersebut berada. Dengan menggunakan influencer lokal, pelaku usaha dapat memperbesar kemungkinan pelanggan di lokasi tersebut untuk datang mengunjungi tempat usaha yang dipromosikan. Atribut kedua, yaitu growth rate, dapat digunakan sebelum memilih influencer untuk mengetahui popularitas influencer saat ini. Growth rate tersebut harus diimbangi dengan riset supaya pelaku usaha tidak memilih influencer yang viral karena sentimen negatif.

3. Diharapkan penelitian selanjutnya dapat mempertimbangkan sentimen influencer sebelum memberikan rekomendasi kepada pelaku usaha

4. Diupayakan sistem rekomendasi bisa mendeteksi influencer yang melakukan kecurangan seperti jual-beli follower, likes, atau komentar untuk meningkatkan atribut ratio atau growth rate mereka.

\section{DAFTAR PUSTAKA}

Aggarwal, C. C. (2016). Recommender Systems: The Textbook. In Springer International Publishing. Springer International Publishing. https://doi.org/10.1145/245108.245121

Anandhan, A., Shuib, L., Ismail, M. A., \& Mujtaba, G. (2018). Social Media Recommender Systems: Review and Open Research Issues. IEEE Access, 6, 15608-15628. https://doi.org/10.1109/ACCESS.2018.2810062 
Backaler, J. (2018). Digital Influence. Palgrave Macmillan. https://doi.org/10.1007/978-3-31978396-3

Carrer-Neto, W., Hernández-Alcaraz, M. L., Valencia-García, R., \& García-Sánchez, F. (2012). Social knowledge-based recommender system. Application to the movies domain. Expert Systems with Applications, 39(12), 10990-11000. https://doi.org/10.1016/j.eswa.2012.03.025

Diamond, S. (2019). Digital Marketing All-in-One. John Wiley \& Sons, Inc.

Dong, M., Zeng, X., Koehl, L., \& Zhang, J. (2020). An interactive knowledge-based recommender system for fashion product design in the big data environment. Information Sciences, 540, 469-488. https://doi.org/10.1016/j.ins.2020.05.094

Gil, M., El Sherif, R., Pluye, M., Fung, B. C. M., Grad, R., \& Pluye, P. (2019). Towards a Knowledge-Based Recommender System for Linking Electronic Patient Records with Continuing Medical Education Information at the Point of Care. IEEE Access, 7, 1595515966. https://doi.org/10.1109/ACCESS.2019.2894421

Isinkaye, F. O., Folajimi, Y. O., \& Ojokoh, B. A. (2015). Recommendation systems: Principles, methods and evaluation. In Egyptian Informatics Journal (Vol. 16, Issue 3, pp. 261-273). Elsevier B.V. https://doi.org/10.1016/j.eij.2015.06.005

Rosa, R. L., Schwartz, G. M., Ruggiero, W. V., \& Rodriguez, D. Z. (2019). A Knowledge-Based Recommendation System That Includes Sentiment Analysis and Deep Learning. IEEE Transactions on Industrial Informatics, 15(4), 2124-2135. https://doi.org/10.1109/TII.2018.2867174

Singh, S. (2010). Social Media Marketing for Dummies. John Wiley \& Sons Canada, Ltd.

Tejeda-Lorente, Á., Bernabé-Moreno, J., Herce-Zelaya, J., Porcel, C., \& Herrera-Viedma, E. (2019). A risk-aware fuzzy linguistic knowledge-based recommender system for hedge funds. Procedia Computer Science, 162, 916-923. https://doi.org/10.1016/j.procs.2019.12.068

Walker, R. J., \& Zimmermann, T. (2014). Recommendation Systems in Software Engineering (Developer Profiles for Recommendation Systems) (M. P. Robillard \& W. Maalej, Eds.). Springer-Verlag Berlin Heidelberg. 